\title{
THE EFFECTS OF A PILATES-AEROBIC PROGRAM ON MAXIMUM EXERCISE CAPACITY OF ADULT WOMEN
}

\author{
EFEITOS DE PROGRAMA DE PILATES AERÓBICO SOBREA CAPACIDADE MÁXIMA DEEXERCÍCIO \\ EMMULHERES ADULTAS
}

Original Article

Artigo Original

Artículo Original

\author{
EFECTOS DE UN PROGRAMA DE PILATES AERÓBICO EN LA CAPACIDAD MÁXIMA DEEJERCICIO \\ ENMUJERES ADULTAS
}

\author{
Milena Mikalački ${ }^{1}$ \\ (Physical Education and Sport \\ Professional) \\ Nebojša Čokorilo \\ (Physical Education and Sport \\ Professional) \\ Pedro Jesús Ruiz-Montero² \\ (Physical Education and Aging \\ Professional) \\ 1. University of Novi Sad, Faculty of \\ Sport and Physical Education, Novi \\ Sad, Serbia. \\ 2. International University of La \\ Rioja, Faculty of Education, \\ La Rioja, Spain.
}

\section{Correspondence:}

Pedro Jesús Ruiz-Montero

Faculty of Education, International

University of La Rioja.

Avenida de la Paz, 137,

Logroño, Spain. 26004.

pedrojesus.ruiz@unir.net

\begin{abstract}
Introduction: Physical exercise such as the Pilates method offers clinical benefits on the aging process. Likewise, physiologic parameters may be improved through aerobic exercise. Methods: In order to compare the differences of a Pilates-Aerobic intervention program on physiologic parameters such as the maximum heart rate (HRmax), relative maximal oxygen consumption (relative VO2max) and absolute (absolute VOmax), maximum heart rate during maximal oxygen consumption (VO2max-HRmax), maximum minute volume (VE) and forced vital capacity (FVC), a total of 64 adult women (active group $=48.1 \pm 6.7$ years; control group $=47.2 \pm 7.4$ years) participated in the study. The physiological parameters, the maximal speed and total duration of test were measured by maximum exercise capacity testing through Bruce protocol. The HRmax was calculated by a cardio-ergometric software. Pulmonary function tests, maximal speed and total time during the physical test were performed in a treadmill (Medisoft, model 870c). Likewise, the spirometry analyzed the impact on oxygen uptake parameters, including FVC and VE. Results: The VO2max (relative and absolute), VE (all, $\mathrm{P}<0.001$ ), VO2max-HRmax ( $P<0.05$ ) and maximal speed of treadmill test $(P<0.001)$ showed significant difference in the active group after a physical exercise interventional program. Conclusion: The present study indicates that the Pilates exercises through a continuous training program might significantly improve the cardiovascular system. Hence, mixing strength and aerobic exercises into a training program is considered the optimal mechanism for healthy aging.
\end{abstract}

Keywords: aging; exercise test; oxygen consumption; exercise.

\section{RESUMO}

Introdução: O exercício físico, como Pilates, proporciona benefícios clínicos no processo de envelhecimento. Do mesmo modo, os parâmetros fisiológicos podem ser melhorados pelo exercício aeróbico. Métodos: A fim de comparar as diferenças de um programa de intervenção com Pilates aeróbico em parâmetros fisiológicos, como frequência cardíaca máxima (FCmáx), consumo máximo de oxigênio relativo (VO2máx relativo) e absoluto (VOmáx absoluto), frequência cardíaca máxima durante o consumo máximo de oxigênio (VO2máx-FCmáx), volume minuto (VM) máximo e capacidade vital forçada (CVF), um total de 64 mulheres adultas (grupo ativo $=48,1 \pm 6,7$ anos, grupo controle = 47,2 $\pm 7,4$ anos) participaram do estudo. Os parâmetros fisiológicos, velocidade máxima e a duração total do teste foram medidos pelo teste de capacidade máxima de exercício pelo protocolo de Bruce. A FCmáx foi calculada por um software cárdio-ergométrico. Os testes de função pulmonar, velocidade máxima e tempo total durante o teste fisico foram realizados em esteira rolante (Medisoft, modelo 870C). Da mesma forma, a espirometria analisou o impacto sobre os parâmetros de captação de oxigênio, incluindo CVF e VM. Resultados: VO2máx (relativo e absoluto), VM (todos, $P<0,001)$, VO2máx- $F C$ máx $(P<0,05)$ e velocidade máxima do teste ergométrico $(P<0,001)$ mostraram diferença significativa no grupo ativo após um programa de intervenção física. Conclusão: Este estudo indica que os exercícios de Pilates por meio de um programa de treinamento contínuo pode melhorar significativamente o sistema cardiovascular. Portanto, a mistura de exercícios de força e aeróbicos em um programa de treinamento éconsiderada o mecanismo ideal para o envelhecimento saudável.

Descritores: envelhecimento; teste de esforço; consumo de oxigênio; exercício.

\section{RESUMEN}

Introducción: El ejercicio físico de Pilates ofrece beneficios clínicos en el proceso de envejecimiento. Del mismo modo, los parámetros fisiológicos se pueden mejorar mediante el ejercicio aeróbico. Métodos: Con el fin de comparar las diferencias de un programa de intervención con Pilates aeróbico en los parámetros fisiológicos, como la frecuencia cardiaca máxima (FCmáx), consumo máximo de oxígeno relativo (VO2máx relativo) y absoluto (VOmáx absoluto), la frecuencia cardiaca máxima durante el consumo máximo de oxígeno (VO2máx-FCmáx), el volumen minuto (VM) máximo (VE) y la capacidad vital forzada (CVF), un total de 64 mujeres adultas (grupo activo $=48,1 \pm 6,7$ años; grupo control = 47,2 $\pm 7,4$ años) participaron en el estudio. Los parámetros fisiológicos, la velocidad máxima y la duración total de la prueba se midieron por la máxima capacidad de ejercicio a través del protocolo de Bruce. La FCmáx se calculó mediante un software cardio-ergométrico. Las pruebas de función pulmonar, la velocidad máxima y el 
tiempo total durante las pruebas físicas fueron realizados en una cinta de correr (Medisoft, modelo 870C). Asimismo, la espirometría analizó el efecto sobre los parámetros de consumo de oxígeno, incluyendo CVFy VM. Resultados: EI VO2máx (relativo y absoluto), VM (todos, $P<0,001$ ), el VO2máx-FCmáx $(P<0,05)$ y la velocidad máxima de prueba de esfuerzo $(P<0,001)$ mostraron una diferencia significativa en el grupo activo después de un programa de intervención física. Conclusión: El presente estudio indica que los ejercicios de Pilates por medio de un programa de entrenamiento continuo puede mejorar significativamente el sistema cardiovascular. Por lo tanto, la mezcla de ejercicios de fuerzay aeróbicos en un programa de entrenamiento es considerada el mecanismo ideal para el envejecimiento saludable.

Descriptores: envejecimiento; prueba de esfuerzo; consumo de oxígeno; ejercicio.

\section{INTRODUCTION}

The main characteristic of ageing is a gradual and inevitable deterioration of physical capacities and degenerative diseases ${ }^{1}$. The physical fitness evolution during the ageing process decreases and it is necessary to guarantee a better understanding of elderly people and reduce their consequences. Moreover, it is common knowledge that ageing causes drastic reduction in physical fitness ${ }^{2}$.

In the mid-nineties, there was a certain evolution in the way of thinking among the people engaged in recreational physical exercising. From that moment on there was the expansion of other group- guided programs, such as Pilates, yoga, Tai - Chi and other "body \& mind" programs on the one hand, and spinning, body pump, step aerobics, aqua aerobics and other "cardio" systems of exercising which put into focus the positive influence of exercising on psycho - physical health and general sense of well-being due to exercising ${ }^{3}$. The Pilates method mixes a philosophy of health and well-being by means of brain cells activation, in turn, stimulating a positive impact on the mind and the body. This method was ranked seventh place by the ACSM as an emerging physical activity in 2008 and 2009, and in the US alone, the number of users reached 10.5 million in $2004^{4}$. The Pilates method coincides with the modern principles of fitness, personal training, and mental happiness through exercises that maintain a neutral spine position and the use of the floor and equipment to develop the physical fitness in general ${ }^{5}$. Therefore, Pilates programs can be physical activities with clinical benefits through several studies on the aging process ${ }^{5,6}$.

Physical fitness is an integrated measurement of cardiorespiratory and endocrine-metabolic functions ${ }^{7}$. The main function of the cardio-vascular and respiratory system is to supply the body with oxygen and nutrients, to release the body from carbon dioxide and metabolic by-products, to maintain the body temperature and acid-base balance and to transport hormones from endocrine glands to the place of their activity $^{8}$. These two systems respond to the increased activity of the skeletal muscles in a relatively predictable. The oxygen consumption efficiency has higher prognostic level than other cardio physiological parameters as the maximum minute ventilation in regard to carbon dioxide production?

The reduction of maximal oxygen uptake increases between $\mathrm{f} 0.5 \%$ 1.0\% per year and it has an influence on the physical fitness on adult and elderly people ${ }^{10}$. The oxygen uptake reserve level establishes a range between 50\%-85\% for aerobic exercises in elderly people, including moderate and vigorous exercises ${ }^{1}$. Later researches, however, showed that when the level of declining of aerobic capability is expressed as a percentage of declining since the early adulthood, then this difference in favour of non-sedentary individuals is lost ${ }^{11}$. Moreover, men and women who do some kind of endurance training, show greater absolute level of decline of aerobic ability (ml. $\mathrm{Kg}(-1)$. min (-1) with age than sedentary adults ${ }^{11}$.
There are a lot of studies about heart rate capacity and cardiovascular system comparing the differences before and after physical exercise training. However, there are not abundant results of studies about physiologic parameters in adult women, specifically FVC, before and after a mix of Pilates method and aerobic exercise. Therefore, the aim of the present study was to compare the differences in maximum exercise capacity and physiological parameters of a sample of adult females during six-months Pilates-Aerobic Interventional Program.

\section{Measures and procedures}

The participants were informed of the purpose of the present study. Written informed consent was obtained from all participants after receiving detailed information about the aims and study procedures of the current project.

Data was collected twice. The present study was initiated in May 2011 with a pre-test and concluded in November 2011, performing a post-test (six months). The interventional program had an 80\% attendance rate during this period. The interventional program consisted of Pilates method and music-based aerobic (Aerobic and steps), basic to intermediate level. The sessions included in this interventional program took place twice per week, and lasted 55-60 minutes per day-session, with an effective physical activity time of 45 minutes, in line with the requirements laid by the $\mathrm{ACSM}^{12}$. The physical fitness of participants and the performance of physical exercises were controlled by specialists. This study was approved by Ethical Committee of University of Novi Sad (114-451-2337/2011) and funded by the Provincial Secretariat for Science and Technological Development: "Impact of Physical Activity on the Risk Factors of the Working Population".

A cross-sectional study was used to assess the oxygen uptake of female adult participants during a treadmill test. Body weight was measured to $\pm 0.1 \mathrm{~kg}$ on an electronic scale (SECA, Hamburg, Germany) with participants wearing light indoor clothing and no shoes. The physiological parameters were measured by maximum exercise capacity testing during the increase of speed and the degree of the ramp level each three minutes through Bruce protocol ${ }^{13}$. Previous to maximum exercise capacity test, all participants answered a standard questionnaire according their medical history, health-related habits and smoking status. Both the questionnaire and the treadmill test were supervised by physicians from University of Novi Sad. The test was interrupted when the female participants reported maximal fatigue. The maximal exertion was determined as achieving $\geq 85 \%$ age-reported maximal heart rate $(\mathrm{HRmax})^{14}$. Moreover, the Borg scale was used to quantify the sensation of shortness of breath during effort and at rest ${ }^{15}$. The HRmax was calculated by cardio-ergometric program software (Cardiovex). Lung function testing and treadmill variables (maximal speed and total time during the test) were performed by treadmill testing (Medisoft, model 870c) and spirometry to analyze the VO2max, including forced vital capacity (FVC) and maximum minute ventilation (VE). 


\section{Statistical analysis}

Normality of distribution was tested by means of the kolmogorov-Smirnov test. Clinical statistical methods were used for the calculations of the means and standard deviation (SD), minimal and maximum values of body composition parameters (age and body weight), physiological variables (HRmax, VO2max, VO2max-Hmax, VE and FVC) and Bruce protocol variables (maximal speed and total time during the test). In order to establish the differences in physiological variables and the Bruce protocol variables in the pre-post test, paired samples T-test was used for two dependent groups of participants. Data were analyzed using the SPSS statistical program (SPSS for Windows 19.0, Inc., Chicago, Illinois, USA). For all analyses, significance was accepted at $\mathrm{P}<0.05$.

\section{RESULTS}

Table 1 shows descriptive parameters of body composition parameters such as age (active group $=48.1 \pm 6.7$ years; control group $=$ $47.2 \pm 7.4$ years) and body weight (active group $=65.7 \pm 6.2$; control group $=66.3 \pm 11.3$ ), maximal heart rate (active group $=173.1 \pm 12.2$; control group $=168.9 \pm 12.3)$, minimum and maximum physiological variables of active group (HRmax= 143-189 bpm; VO2max relative $=20.6-37.6$ $\mathrm{ml} / \mathrm{kg} / \mathrm{min}$; VO2max absolute= 1.2-2.4 l/m; VO2max-Hmax= 134-189; $\mathrm{VE}=38.2-86.1 \mathrm{l} / \mathrm{min}$ and $\mathrm{FVC}=2.2-5.5 \mathrm{I})$ and control group (HRmax $=145-185$ bpm; VO2max relative $=19.8-35.9 \mathrm{ml} / \mathrm{kg} / \mathrm{min} ; \mathrm{VO} 2 \mathrm{max}$ absolute $=1.2-2.4$ $\mathrm{l} / \mathrm{m}$; VO2max-Hmax= 144-183; $\mathrm{VE}=36.2-80.3 \mathrm{l} / \mathrm{min}$ and $\mathrm{FVC}=2.2-5.2 \mathrm{l}$ ).

Finally, Bruce protocol variables were also descriptive in active group (maximal speed $=4-6.8 \mathrm{~km} / \mathrm{h}$; total time during the test $=3.31-10.01$ minutes) and control group (maximal speed $=4-6.7 \mathrm{~km} / \mathrm{h}$; total time during the test $=4.28-9.04$ minutes). Hence, the differences between minimal and maximum physiological parameters values of active and control group are scarce except VO2max-HRmax and VE (I/min). Regarding to treadmill test, the maximum speed between two groups studied is very similar

Table 1. Clinical and physiological characteristics of the study sample by groups. ( $N=64)$.

\begin{tabular}{c|c|c|c|c|c|c}
\hline & \multicolumn{3}{|c|}{ Active group ( $\mathbf{n}=36)$} & \multicolumn{3}{c}{ Control group ( $=\mathbf{2 8})$} \\
\hline & Mean (SD) & Min & Max & Mean (SD) & Min & Max \\
\hline Age (years) & $48.1(6.7)$ & 41 & 59 & $47.2(7.4)$ & 40 & 59 \\
\hline Body Weight (kg) & $65.7(6.2)$ & 47.1 & 78.1 & $66.3(11.3)$ & 46.0 & 88.0 \\
\hline HRmax (bpm) & $173.1(12.2)$ & 143 & 189 & $168.9(12.3)$ & 145 & 185 \\
\hline Physiological variables & & Min & Max & & Min & Max \\
\hline $\begin{array}{c}\text { VO2max (ml/kg/min) } \\
\text { (relative) }\end{array}$ & & 20.6 & 37.6 & & 19.8 & 35.9 \\
\hline VO2max (I/m)(absolute) & & 1.2 & 2.4 & & 1.2 & 2.4 \\
\hline VO2max-HRmax & & 134.0 & 189.0 & & 144 & 183 \\
\hline VE (I/min) & & 38.2 & 86.1 & & 36.2 & 80.3 \\
\hline FVC (I) & & 2.2 & 5.5 & & 2.2 & 5.2 \\
\hline $\begin{array}{c}\text { Bruce protocol } \\
\text { (treadmill test ) }\end{array}$ & & & & & & \\
\hline Max speed (km/h) & & 4.0 & 6.8 & & 4.0 & 6.7 \\
\hline Total time duration & & 3.31 & 10.01 & & 4.28 & 9.04 \\
\hline
\end{tabular}

Note. $\mathrm{SD}=$ Standard Deviation, Min= Minimum, Max= Maximum, HRmax= Maximum heart rate, VO2max= Maxima oxygen consumption, $\mathrm{VO} 2 \mathrm{max}-\mathrm{Hmax}=$ Maximum heart rate during maximal oxygen consumption, $\mathrm{VE}=$ Maximum minute ventilation, $\mathrm{FVC}=$ Forced vital capacity whereas the total time during the exercise capacity test of active group presents less minimal time and higher maximum time of testing.

Table 2 shows descriptive physiological parameters and treadmill test values: mean, standard deviation (SD), pre-test/post-test and p-value. According to physiological parameters, there was differences in VO2 max (relative), VO2max (absolute), VE (all, $\mathrm{P}<0.001$ ), and VO2max-HRmax (both, $P<0.05$ ) of the active group after a physical exercise interventional program. The variable of treadmill test showed difference in maximum speed $(\mathrm{P}<0.001)$. However, control group showed no significant differences during the period of 24 weeks-physical exercise interventional program.

\section{DISCUSSION}

The present study shows the improvement of an interventional program consisted of Pilates method and music-based aerobic (Aerobic and steps) in the maximum exercise capacity and physiological parameters of female participants.

All physiological parameters studied (VO2 max (relative), VO2max (absolute), VE and VO2max-HRmax, except the FVC, experienced significant differences after a Pilates-Aerobic interventional program in the adult women studied. Nevertheless, the differences in physiological parameters and maximum exercise capacity of control group were not significant. The maximal oxygen uptake in the interventional group after the PilatesAerobic exercise intervention experienced an increase of relative oxygen consumption of two and half percent whereas the VO2max (absolute) experienced a minimal increase. Similarly, Pantelić et al. ${ }^{16}$, in a sample of 59 adult women, found statistically significant difference in physiological variables for evaluation of maximal capacity exercise between the initial and final measuring in the participant group of aerobic exercise program, while in the control group there was no significant difference. The results of the final measuring from the present interventional study have also shown that the created model of Pilates-Aerobic exercise shows positive effects on the physiological parameters in the participants of the active group. According to the conclusions of Deci and Ryan ${ }^{17}$, participants of imposed exercise programs by different high intensity interventions, could report important physiological adaptations.

Moreover, exercise of moderate intensity such as the interventional program of the present study, experiences different types of affective response to physiological parameters of participants ${ }^{18}$ as for example the FVC. The main cause of those different responses may be explained because of the relation of physiologic responses with the intensity of the exercise ${ }^{19}$. Likewise, the knowledge about physiological response to exercise in older adults is still scarce ${ }^{20}$. However, the VO2max-HRmax of participants in the interventional group experienced a minimal significant increase while the participants of the control group decreased. In the line of Smith, et al. ${ }^{20}$ study, this physiologic parameter might increase because of singularity and effort of treadmill test but others studies have shown differences in VO2max and VO2max-HRmax with similar population in a fitness and aerobic exercise interventional program²1.

Table 2. Difference between study samples by groups in clinical parameters, physiological parameters and treadmill test.

\begin{tabular}{|c|c|c|c|c|c|c|}
\hline \multirow[b]{2}{*}{ Physiological parameters } & \multicolumn{3}{|c|}{ Active group $(n=36)$} & \multicolumn{3}{|c|}{ Control group $(n=28)$} \\
\hline & $\begin{array}{c}\text { Pre } \\
M(S D)\end{array}$ & $\begin{array}{c}\text { Post } \\
\text { M (SD) }\end{array}$ & p-value & $\begin{array}{c}\text { Pre } \\
M(S D)\end{array}$ & $\begin{array}{c}\text { Post } \\
\text { M (SD) }\end{array}$ & p-value \\
\hline VO2max (ml/kg/min)(relative) & $27.5(4.1)$ & $30.1(4.2)$ & 0.00 & $28.3(4.8)$ & $27.5(5.1)$ & 0.06 \\
\hline VO2max (l/m)(absolute) & $1.8(0.3)$ & $1.9(0.3)$ & 0.00 & $1.8(0.3)$ & $1.7(0.3)$ & 0.20 \\
\hline VO2max-HRmax & $168.7(14.2)$ & $169.2(11.9)$ & 0.03 & $165.4(12.8)$ & $164.8(11.8)$ & 0.52 \\
\hline $\mathrm{VE}(\mathrm{I} / \mathrm{min})$ & $63.1(10.9)$ & $71.3(13.8)$ & 0.00 & $59.9(12.1)$ & $59.6(12.2)$ & 0.67 \\
\hline FVC $(I)$ & $3.7(0.6)$ & $3.8(0.7)$ & 0.15 & $3.6(0.6)$ & $3.5(0.6)$ & 0.33 \\
\hline \multicolumn{7}{|l|}{ Bruce protocol (treadmill test) } \\
\hline Max speed $(\mathrm{km} / \mathrm{h})$ & $5.6(0.8)$ & $5.9(0.7)$ & 0.00 & $5.4(0.7)$ & $5.2(0.6)$ & 0.29 \\
\hline Total time duration & $7.2(1.7)$ & $8.1(1.5)$ & 0.09 & $6.7(1.2)$ & $6.3(1.2)$ & 0.61 \\
\hline
\end{tabular}

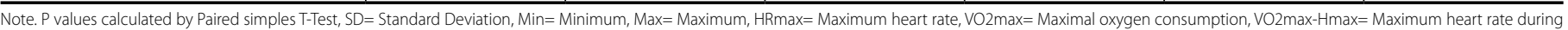
maximal oxygen consumption, $\mathrm{VE}=$ Maximum minute ventilation, $\mathrm{FVC}=$ Forced vital capacity. 
The ACSM ${ }^{1}$ and other authors ${ }^{16,22,23}$ recommend following international exercise guidelines and experts where is described that the characteristics of an exercise program should contain continual sessions of 40-45 minutes with a intensity frequency between $50 \%-80 \%$, whether the main objective of the exercise program is a improvement of VO2max, and VO2max-HRmax. According to the last assertion, an improvement of $\mathrm{VO} 2 \mathrm{max}$ and maximal exercise capacity occurred after a fitness-aerobic (bench-step) exercise program with adult women ${ }^{24}$. If physical exercise program with adult and elderly people do not follow international guidline, it is possible that the benefits would not be the expected. Similarly, the normal lung volume and VO2max decrease during the practice of exhaustive exercise ${ }^{25}$. Then, the physical exercise has a positive effect on improving maximal exercise capacity which has been shown in the results of the present study, considering that aerobic ability usually reaches its peak in the period between the age of 15 and $20^{11,26}$.

According to the pulmonary ventilation, the participants of the interventional group on final measuring achieved better values of variable VE compared to the control group whose values were similar and without significance differences. The rise in VE could be related to the increase of VO2max-HRmax because of high intensity of a maximal cardio-pulmonary exercise which is related with $\mathrm{VO} 2 \mathrm{max}$ relative according to American Thoracic Society (ATS) and American College of Chest Physicians (ACCP) ${ }^{23}$. The Oliver et al. ${ }^{27}$ study where the increase of VE was related to maximal capacity exercise, showed similar physiologic parameters with participants of similar age but more weight. The results of the present study prove that respiratory system represents a limiting factor during the physical activity, especially in elderly people. Pulmonary ventilation represents the parameter of economical capacity; more precisely represents the product of frequency of breathing and depth of inhaling during various loads. The one physiologic parameter without significant difference after the intervention neither the interventional group nor the control group is the FVC. However, the FVC improved in others studies as in a group of female participants ranged 40 years and more who participated in an interventional aerobic program ${ }^{28}$

Finally, the total duration of treadmill test in active group increased after the interventional exercise program when the total duration of control group decreased. Several studies have proved that the combination of strength and aerobic exercise may be more effective on the cardio-vascular system and skeletal muscle mass in adult and elderly people ${ }^{6,22}$. Therefore, the participants of the active group could have improved the strength and physiological parameters after a Pilates-Aerobic interventional program and walking faster than participants of control group who was measured without to practice any physical activity guided.

Several limitations of this study need to be mentioned. Firstly, the study was conducted just with female patients and thus, generalization of the results to older adult men should be avoided. Secondly, the sample used in both groups was scarce. Similar researches should be conducted with adequate representation of populations with different illness and bigger range of age to enable a comparison between control group and active participants.

\section{CONCLUSION}

In conclusion, the study indicates that the recreational exercise and continuous training program might significantly improve several physiologic parameters of adult women such as cardio-vascular system (relative and absolute VO2max, VO2max-HRmax and VE), which is important for women with similar age than the present participants. The loss of maximal capacity exercise can lead to the poorer quality of life. Larger differences in the $\mathrm{VO} 2$ max values in groups that regularly have recreational trainings might be connected with their higher values in youth (base effect) or with a larger reduction of exercises in the elderly age. Hence, a mix of strength and aerobic exercise training program is considered as an optimal mechanism of a healthy aging.

\section{ACKNOWLEDGMENTS}

A special thanks to all who participated in this study, and to any inconvenience it may have caused them. Also, to the final year students at the Faculty of Sport and Physical Education, University of Novi (Serbia) and the colleagues from this Faculty who provided participants, material and space for this research.

All authors declare no potential conflict of interest related to this article.

AUTHORS' CONTRIBUTIONS: Each author contributed individually and significantly to the development of the manuscript. MM (0000-0002-9561-1992)* , NC (0000-00018767-7839)* and PJRM (0000-0003-0154-1936)* were the main contributors in the drafting of the manuscript. MM and NC underwent intervention, followed patients and gathered socio-demographic and clinical data. MM, NC and PJRM evaluated the data of the statistical analysis. MM, NC and PJRM performed the literature search, review of the manuscript and contributed to the intellectual concept of the study. ${ }^{*} \mathrm{ORCID}$ (Open Researcher and Contributor ID).

\section{REFERENCES}

1. Nelson ME, Rejeski WJ, Blair SN, Duncan PW, Judge JO, King AC, et al. Physical activity and public health in older adults: recommendation from the American College of Sports Medicine and the American Heart Association. Circulation. 2007;116(9):1094-105.

2. Aparicio V, Carbonell-Baeza A, Delgado-Fernández M. Health benefits of physical activity in older people Rev Int Med Cienc Act Fís Deporte. 2010;10(40): 556-76.

3. Kenedy C, Yoke M. Methods of group exercise instruction. Champaign, IL: Human Kinetics; 2005.

4. Thompson WR. Worldwide survey reveals fitness trends for 2010. ACSM'S Healt Fit J. 2009;13(6);9-16.

5. Levine B, Kaplanek B, Jaffe WL. Pilates training for use in rehabilitation after total hip and knee arthroplasty: a preliminary report. Clin Orthop Relat Res. 2009;467(6):1468-75.

6. Ruiz-Montero PJ, Castillo-Rodriguez A, Mikalački M, Nebojsa C, Korovljev D. 24-weeks Pilates-aerobic and educative training to improve body fat mass in elderly Serbian women. Clin Interv Aging. 2014;9:243-8.

7. Castillo-Garzón MJ, Ruiz JR, Ortega FB, Gutiérrez A. Anti-aging therapy through fitness enhancement Clin Interv Aging. 2006; 1(3):213-20

8. Wilmore JH, Costill DL. Physiology of sport and exercise. Champaign, IL: Human Kinetics; 2005

9. Davies LC, Wensel R, Georgiadou P, Cicoira M, Coats AJ, Piepoli MF, et al. Enhanced prognostic value from cardiopulmonary exercise testing in chronic heart failure by non-linear analysis: oxygen uptake efficiency slope. Eur Heart J. 2006;27(6):684-90.

10. Fleg JL, Morrell CH, Bos AG, Brant LJ, Talbot LA, Wright JG, Lakatta EG. Accelerated longitudinal decline of aerobic capacity in healthy older adults. Circulation. 2005;112(5):674-82.

11. Eskurza I, Donato AJ, Moreau KL, Seals DR, Tanaka H. Changes in maximal aerobic capacity with age in endurance-trained women: 7-yr follow-up. J Appl Physiol (1985). 2002;92(6):2303-8.

12. ACSM's Guidelines for Exercise Testing and Prescription. 8th ed. Philadelphia: Lippincott; 2009.

13. Bruce RA, Kusumi F, Hosmer D. Maximal oxygen intake and nomographic assessment of functional aerobic impairment in cardiovascular disease. Am Heart J. 1973;85(4):546-62.

14. Erez A, Kivity S, Berkovitch A, Milwidsky A, Klempfner R, Segev S, et al. The association between cardiorespiratory fitness and cardiovascular risk may be modulated by known cardiovascular risk factors. Am Heart J. 2015:169(6):916-923.

15. Borg GA. Psychophysical bases of perceived exertion. Med Sci Sports Exerc. 1982;14(5):377-81.

16. Pantelić S, Kostić R, Mikalački M, Đurašković R, Čokorilo N, Mladenović I. The effects of a model of recreational aerobic exercise training on functional abilities of women. Facta Universitatis. Series: Physical Education and Sport. 2007;5(1);19-35. Disponível em: http://facta.junis.ni.ac.rs/pe/pe200701/pe200701-03.pdf

17. Deci EL, Ryan RM. The 'What' and 'Why' of goal pursuits: human needs and the self-determination of behavior. Psychol Inq. 2000;11:227-68

18. Ekkekakis P, Parfitt G, Petruzzello SJ. The pleasure and displeasure people feel when they exercise at different intensities: decennial update and progress towards a tripartite rationale for exercise intensity prescription. Sports Med. 2011;41(8):641-71.

19. Acevedo EO, Ekkekakis P. Psychobiology of physical activity. Leeds: Human Kinetics; 2006

20. Smith AE, Eston R, Tempest GD, Norton B, Parfitt G. Patterning of physiological and affective responses in older active adults during a maximal graded exercise test and self-selected exercise. Eur J Appl Physiol. 2015;115(9):1855-66.

21. Kostić $R$, Zagorc M. A comparison of the changes in cardio-vascular fitness from two models of women aerobic training. Facta Universitatis. Series: Physical Education and Sport. 2005;3(1):45-57. Disponível em: http://facta.junis.ni.ac.rs/pe/pe2005/pe2005-05.pdf

22. American College of Sports Medicine, Chodzko-Zajko WJ, Proctor DN, Fiatarone Singh MA, Minson CT, et al. American College of Sports Medicine position stand. Exercise and physical activity for older adults Med Sci Sports Exerc. 2009;41(7):1510-30

23. American Thoracic Society:; American College of Chest Physicians.. ATS/ACCP Statement on cardiopulmonary exercise testing. Am J Respir Crit Care Med. 2003;167(2):211-77.

24. KraemerWJ, Keuning M, Ratamess NA, Volek JS, McCormick M, Bush JA, et al. Resistance training combined with bench-step aerobics enhances women's health profile. Med Sci Sports Exerc. 2001;33(2):259-69.

25. Gallagher CG, Hof VI, Younes M. Effect of inspiratory muscle fatigue on breathing pattern. J Appl Physiol (1985). 1985;59(4):1152-8.

26. Buskirk ER, Hodgson JL. Age and aerobic power: the rate of change in men and women. Fed Proc 1987:46(5):1824-9.

27. Oliver N, Onofre T, Carlos R, Barbosa J, Godoy E, Pereira E, et al. Ventilatory and Metabolic Response in the Incremental Shuttle and 6-Min Walking Tests Measured by Telemetry in Obese Patients Prior to Bariatric Surgery. Obes Surg. 2015;25(9):1658-65

28. Janyacharoen T, Phusririt C, Angkapattamakul S, Hurst CP, Sawanyawisuth K. Cardiopulmonary effects of traditional Thai dance on menopausal women: a randomized controlled trial. J Phys Ther Sci. 2015:27(8):2569-72 